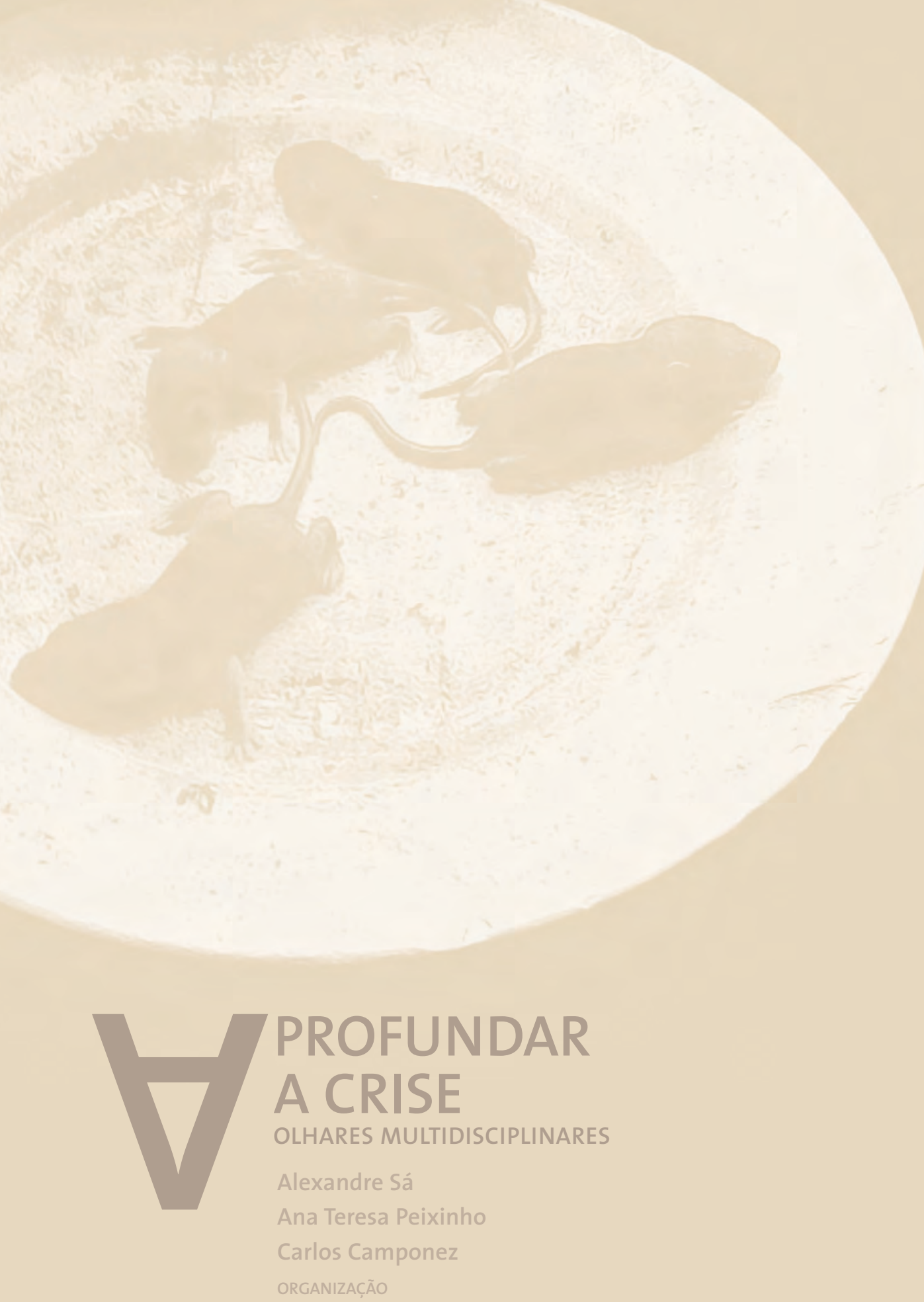




\section{A Crise atual do capitalismo: CRISE ESPERADA E QUASE PROGRAMADA ${ }^{148}$}

1. Toda a construção liberal assenta na ideia de que o melhor dos mundos se atinge, graças à mão invisível inventada por Adam Smith, deixando funcionar o mercado para que a taxa de lucro possa crescer, e, com ela, o investimento, o crescimento económico e o bem-estar para todos.

Este otimismo dos clássicos ingleses acerca das possibilidades de crescimento sem limites e da melhoria generalizada das condições de vida vinha reforçado pela confiança na Lei de Say, segundo a qual não são possíveis crises de sobreprodução generalizadas, e pela convicção de que, em virtude de leis naturais, os salários nunca poderiam, duradouramente, ultrapassar o valor correspondente ao mínimo de subsistência.

Este o enquadramento que justificava o paraíso liberal (o mesmo dos neoliberais dos nossos dias).

A verdade, porém, é que Malthus e depois Marx, cada um à sua maneira, vieram mostrar o que a vida confirmaria: as crises cíclicas de sobreprodução são inerentes ao capitalismo. Perante a evidência da Grande Depressão, o próprio Keynes reconheceu que, nas sociedades capitalistas, as situações de pleno emprego são raras e efémeras.

\footnotetext{
148 Este artigo foi escrito originariamente para um livro de homenagem ao Professor Eros Roberto Grau, Professor Titular Jubilado da Faculdade de Direito da USP, que deverá vir a público em São Paulo (Brasil) durante este ano de 2012. Utilizo neste texto reflexões inseridas no livro As Voltas que o Mundo Dá... Reflexões a Propósito das Aventuras e Desventuras do Estado Social, Edições Avante, Lisboa, 2010 (editado posteriormente no Brasil, com algumas alterações, pela editora Lumen Juris, Rio de Janeiro, 2011) e desenvolvidas, no momento em que escrevo esta nota (início de maio de 2012), em outro livro que entretanto publiquei: A Crise do Capitalismo: Capitalismo, Neoliberalismo, Globalização, Lisboa, Página a Página, 2012.
} 
A crise que agora abala o mundo é, pois, mais uma crise do capitalismo, uma "crise estrutural do capitalismo". ${ }^{149}$

2. Os factos dão razão ao velho Keynes, que, há mais de 50 anos, advertia para os perigos de paralisação da atividade produtiva em consequência do aumento da importância dos mercados financeiros e da finança especulativa.

Talvez por isso a ideologia dominante se tenha apressado a decretar a "morte de Keynes”, 'sacrificado' no altar dos deuses do neoliberalismo. Desmantelada a regulamentação da atividade bancária e financeira, o capital financeiro ficou inteiramente livre para estabelecer o seu império, com a cumplicidade ativa de uma regulação amiga do mercado.

A ação do capital financeiro especulador acabou por anular as políticas nacionais de regulação das taxas de câmbio, uma vez que as autoridades competentes de muitos países ficaram sem meios para se defender eficazmente da ação dos especuladores. Basta recordar que o montante das reservas detidas pelos bancos centrais de todo o mundo (principal meio de defesa das moedas nacionais) é sensivelmente igual ao montante das transações diárias no mercado cambial (em grande parte puramente especulativas).

Por outro lado, o poder político do capital financeiro desmantelou todas as estruturas e mecanismos de regulação e de controlo da atividade financeira, que vinham dos tempos do combate à grande depressão dos anos 1930, a primeira grande crise do capitalismo marcada pelo predomínio do capital financeiro e pela especulação financeira.

2.1. A aceleração do processo de inovação financeira traduziu-se, nomeadamente, no desenvolvimento dos mercados de produtos financeiros derivados. Chamam-lhe produtos para criar a ilusão de que resultam de uma qualquer 'indústria' (também se fala da indústria bancária...) ou de outra atividade produtiva, mas essa é, a todas as luzes, uma designação falsa, enganadora e não inocente.

149 Cfr. G. DUMÉNIL e D. LÉVY, The Crisis..., cit. 
Criados como instrumentos de gestão dos riscos inerentes à instabilidade das taxas de juro e das taxas de câmbio, estes 'produtos' transformaram-se de imediato em instrumentos destinados apenas a alimentar as 'apostas' na bolsa (o grande casino do capital financeiro), dada a pequena percentagem do capital investido em relação aos ganhos possíveis, e revelaram-se um novo e poderoso fator de instabilidade dos mercados financeiros. ${ }^{150}$

Trata-se de produtos virtuais, cujo valor global se calcula em cerca de mil biliões de dólares (o equivalente a vinte anos da produção mundial!), mal conhecidos, que não têm qualquer relação com a economia real e com as atividades produtivas (criadoras de riqueza). É capital puramente fictício, cujo valor é fixado em função dos ganhos que os 'apostadores' prevêem que podem obter, chamando a si uma parte significativa da riqueza criada pela economia real. Estes 'produtos', cada vez mais sofisticados, servem apenas para ganhar dinheiro com a especulação, atraindo bancos, seguradoras, sociedades gestoras de fundos de investimento e de fundos de pensões.

O recurso abusivo à sua emissão e comercialização conduziu rapidamente à manipulação e à instabilidade dos 'mercados financeiros', porque os contornos e os riscos que esses 'produtos' incorporam nem sempre são facilmente identificáveis, mesmo pelos habituais frequentadores deste 'casino' (como os bancos), que compram muitas vezes 'produtos financeiros' tão esotéricos que não sabem exatamente o que estão a comprar.

Na última década do século xx, o volume das transações sobre os mais perigosos destes 'produtos', os chamados over-the-counter derivative markets, aumentou de 24, 6 mil milhões de dólares em 1992 para 94, 6 mil milhões de dólares em 1999 (um aumento de quase 285\%!). O Relatório Podimata (aprovado pelo Parlamento Europeu em fevereiro/2011) salienta que, em termos globais, o volume das transações financeiras, muitas delas implicando a exposição em elevado grau de capitais alheios nos 'jogos de casino', aumentou sempre ao longo da década que terminou em 2007, em especial devido ao incremento das transações sobre produtos derivados, tendo atingido neste ano um valor igual a 73, 5 vezes o PIB nominal mundial. ${ }^{151}$

150 Para uma visão um pouco mais ampla deste processo de inovação financeira, ver A. J. AVELÃS NUNES, O Crédito..., cit., 201-239.

151 Cfr. Relatório Podimata, 5. 
2.2. Os especialistas avisaram que este fenómeno (completamente alheio às necessidades da economia real), para além de expor as instituições financeiras aos riscos máximos inerentes à natureza volátil destes 'produtos', tornava muito mais difíceis o controlo pelas autoridades de supervisão e a auditoria das contas daquelas instituições. ${ }^{152}$ Os seus defensores, porém, não se cansavam de proclamar as 'virtudes globais' de tais produtos: "Formas inteiramente novas de instrumentos financeiros tiveram de ser inventadas ou desenvolvidas - derivativos de crédito, títulos lastreados em ativos, futuros de petróleo e congéneres, que criam condições para o funcionamento muito mais eficiente do sistema de comércio mundial". É este o ponto de vista de Alan Greenspan. ${ }^{153}$

Para além dos riscos inerentes à proliferação dos produtos derivados, a liberalização dos movimentos de capitais, ao serviço do objetivo de criar um mercado único do capital à escala mundial, arrastou consigo um conjunto de alterações que vieram potenciar fortemente a ameaça de risco sistémico. ${ }^{154}$

Com efeito, a internacionalização dos mercados de valores mobiliários veio colocar em rede mercados muito diferentes, cada um com as suas regras de funcionamento e os seus riscos específicos, abrindo caminho à propagação contagiosa dos fatores de risco.

Por outro lado, a ausência de controlo dos mercados financeiros e dos movimentos de capitais pelos estados nacionais provocou uma onda sem precedentes de concentrações, de fusões e de aquisições de empresas financeiras, com a redução acentuada do número de bancos (que controlam companhias de seguros e, direta ou indiretamente, outras instituições financeiras, nomeadamente sociedades gestoras de fundos de investimento e de fundos de pensões), a concentração nos maiores deles da parte de leão dos depósitos bancários e a preponderância dos grandes bancos nas operações de fusão e aquisição de empresas do setor financeiro.

Um estudo recente de três investigadores do Instituto Federal Suíço de Tecno$\operatorname{logia}^{155}$ dá-nos conta do grau de concentração do poder económico-financeiro ao nível dos centros de decisão a nível mundial. Partindo da definição de empresas

152 Cfr. J. M. QUELHAS, ob. cit., 442.

153 Cfr. A. GREENSPAN, A Era..., cit., 355 [usamos a tradução brasileira].

154 Para maiores desenvolvimentos, ver J. M. QUELHAS, ob. cit., 439-441.

155 O referido estudo foi divulgado em Zurique em 28.7.2011 e está disponível em http://arxiv. org/abs/1107.5728v2. 
transnacionais adotada pela OCDE, os autores selecionaram 43.060 empresas de entre as registadas no banco de dados Orbis 2007.

Neste conjunto de empresas, detetaram mais de 600 mil participações diretas e mais de um milhão de participações indiretas no capital de outras empresas. De entre elas, apuraram um núcleo constituído pelas 1318 mais poderosas empresas transnacionais, que representam diretamente $20 \%$ do rendimento global.

Uma análise mais fina permitiu-lhes concluir que cada uma destas empresas tem, em média, participações no capital de 20 outras grandes empresas, o que permite a este grupo de 1318 empresas transnacionais deter ou controlar, em conjunto, cerca de $60 \%$ da economia mundial.

Dentro deste grupo, o estudo identificou um núcleo mais restrito de 147 entidades (3/4 das quais são instituições financeiras: bancos, seguradoras, fundos de investimento, fundos de pensões) que dominam grande parte das restantes: menos de $1 \%$ das entidades estudadas controlam $40 \%$ de toda a rede. Acresce que estas 147 entidades nucleares estão ligadas entre si por uma densa teia de participações cruzadas, o que faz delas o verdadeiro 'governo' do mundo capitalista. Ficamos a saber o que são "os mercados" e compreendemos que estes "mercados" não sejam compatíveis com a democracia.

Em outro plano, compreendemos que, neste mundo controlado pelo capital financeiro, falar de concorrência não faz qualquer sentido. E compreendemos também que a concentração do capital se traduziu na supremacia do capital financeiro, que controla os centros de decisão à escala mundial. Fica claro o significado último da tão falada financeirização da economia. E fica claro também porque é que o fenómeno descrito, para além de acentuar a supremacia do capital financeiro sobre o capital produtivo, veio facilitar o contágio dos riscos entre os vários componentes do mesmo grupo, propiciando a convergência e a acumulação do risco em um núcleo mais restrito de centros de decisão. Nisto consiste o risco sistémico: se uma destas entidades entra em colapso, a doença pode transformar-se rapidamente em pandemia à escala global.

2.3. Igualmente relevantes, para a problemática que vimos analisando, são as consequências da desregulamentação da atividade bancária, da atividade seguradora e das atividades que decorrem nos mercados de valores mobiliários. 
A onda de desregulamentação terá começado nos EUA, com a abolição das restrições à definição e exploração das rotas da aviação comercial, obra da Administração Carter. E a onda prosseguiu o seu caminho, até provocar um verdadeiro tsunami desregulamentador, que atingiu outros setores da atividade económica, entre os quais as telecomunicações, os media e os serviços financeiros.

Durante a Administração Clinton, os bancos comerciais e os bancos de investimento (obrigatoriamente separados por força de legislação promulgada na sequência da Grande Depressão) foram autorizados a juntar-se, dando origem aos chamados conglomerados financeiros, verdadeiros supermercados de serviços financeiros. A revogação (em 1999) do Glass-Seagall Act (de 1933) pelo Gramm-Leach-Bliley Act libertou o setor financeiro das 'peias' da regulação introduzida durante o New Deal, permitindo aos bancos comerciais negociar com valores mobiliários e 'investir' na bolsa, isto é, jogar no casino. Também sob a responsabilidade da Administração Clinton, foi adotado (em 2000) o Commodities Futures Modernization Act, que veio libertar de qualquer controlo os produtos financeiros derivados de maior risco.

O chamado princípio da banca universal veio permitir aos bancos alargar a sua atividade para além das áreas tradicionais do 'comércio bancário', tendo-se multiplicado os produtos mistos (bancassurance, v.g.) e tendo-se verificado uma integração crescente dos vários mercados financeiros (banca, seguros, moedas e títulos).

O desenvolvimento acelerado daqueles poderosíssimos conglomerados financeiros veio aumentar enormemente o seu poder (incluindo o seu 'poder político') e veio tornar muito mais complexas e difíceis as atividades de regulação e de supervisão de cada um dos setores de atividade financeira, o que constitui mais um fator a potenciar o risco sistémico.

2.4. Conscientes dos perigos destas políticas, alguns especialistas vinham defendendo o desmantelamento dos conglomerados financeiros, instituindo de novo a separação rigorosa entre bancos comerciais e bancos de investimento e separando claramente a função bancária da função seguradora, impedindo os bancos de exercer atividades próprias das empresas seguradoras. Assim se evitaria, pelo menos, o financiamento das atividades especulativas com o dinheiro dos 
depositantes, que passaria a financiar a concessão de crédito às empresas e às famílias, impulsionando a criação de emprego e de riqueza, em vez de alimentar as rendas do capital financeiro.

Os estudos mais consistentes e mais informados sobre a matéria justificavam os sucessivos alertas para os perigos do risco sistémico inerente à disseminação dos produtos financeiros derivados, no quadro de um mercado financeiro único de dimensões planetárias, onde impera a plena liberdade de circulação de capitais. À semelhança do que a teoria refere para os mercados de oligopólio, também neste mercado financeiro global os operadores tendem a atuar em função daquilo que eles pensam que será o comportamento dos demais operadores. A turbulência causada pela especulação em um dado país ou região tende a propagar-se a todo o sistema financeiro mundial graças ao comportamento mimético dos grandes especuladores. O risco sistémico é, assim, o risco global de desmoronamento do sistema financeiro à escala mundial. A consciência disto mesmo é que dá sentido à tese dos que, há uns anos a esta parte, vêm defendendo que tais 'produtos' ameaçavam transformar-se em "armas de destruição maciça".

Estas 'armas' são livremente produzidas e utilizadas pelos conglomerados financeiros acima referidos. Mais uma razão para justificar a adoção de medidas com vista ao seu desmantelamento. Os governantes de serviço, porém, nada fizeram neste sentido, antes proclamaram a plena liberdade de ação do capital como o valor supremo a acautelar.

3. As crises recorrentes das últimas décadas, com início no crash da bolsa de Nova York em 1967, foram claros anúncios da crise atual.

Um primeiro sinal da crise estrutural do capitalismo foi a rotura unilateral dos Acordos de Bretton Woods por parte dos EUA (agosto/1971) e a chamada crise do petróleo (1973 e 1975), à qual se seguiria uma outra 'crise do petróleo' em 1978-1980. Estes dois episódios, no início e no fim da década de 1970, anunciaram o esgotamento do keynesianismo, apanhado de surpresa pelo aparecimento da estagflação, estranho fenómeno que, contrariando o modelo histórico das crises do capitalismo e o otimismo dos defensores do capitalismo post-cíclico, veio mostrar que as crises cíclicas continuavam a caraterizar a vida do capitalismo e que, no quadro de um capitalismo altamente monopolizado, podiam 
perfeitamente coexistir preços altos, com taxas elevadas e crescentes de inflação, e taxas de crescimento do produto próximas de zero (ou mesmo negativas), acompanhadas de desemprego crescente.

Ficou patente que a capacidade de produção instalada no mundo capitalista era excessiva relativamente ao poder de compra agregado da população e ficou patente também que as grandes empresas monopolistas tinham suficiente poder de mercado para impedir a queda dos preços, mantendo a sua espiral ascendente, com a cobertura da subida dos preços do petróleo.

O alarme foi tal que Henry Kissinger, então ao leme da diplomacia norte-americana, chegou a ameaçar com a intervenção militar dos EUA se os países exportadores de petróleo não aceitassem baixar os preços do ouro negro. A estratégia imperialista de domínio dos circuitos de produção e de distribuição do petróleo e do gás natural tem aqui a sua origem, tendo desembocado na invasão e destruição do Iraque, na ocupação do Afeganistão, na guerra contra a Líbia, na ameaça de guerra contra o Irão, no congelamento da solução do problema do Médio Oriente. É o cheiro do petróleo e não o sangue das vítimas inocentes dos movimentos de protesto no mundo árabe que está a perturbar os dirigentes das potências ocidentais, que sempre apoiaram - e continuam a apoiar - todas as ditaduras dos 'reis do petróleo' e outras ditaduras 'amigas' (algumas impostas aos respetivos povos pelas "democracias ocidentais").

Mas esta crise da primeira metade da década de 1970 trouxe à luz do dia a tendência para a baixa da taxa de lucro, que se vinha observando com clareza, especialmente a partir de meados dos anos 1960, nas mais importantes economias capitalistas (baixa de 33\% no Japão; 30\% nos EUA e 19\% na Alemanha). ${ }^{156}$ E a tendência para a baixa da taxa de lucro é, em última instância, a causa primeira das crises do capitalismo, da dita crise do petróleo e da crise atual, no início da segunda década do terceiro milénio. ${ }^{157}$

No rescaldo das dificuldades da primeira metade da década de 1970, o consenso keynesiano foi substituído pelo chamado Consenso de Washington, o consenso entre os EUA e as agências internacionais relacionadas com a economia (FMI, Banco Mundial e GATT/OMC), que se enquadra na estratégia para travar aquela perigosa tendência no sentido da baixa da taxa de lucro.

\footnotetext{
156 Cfr. P. CARVAlHO, "A Crise..., cit., 95.

157 Sobre este ponto, ver G. DUMÉNIL e D. LÉVY, "The Profit Rate..., cit.
} 
Trata-se de um consenso no sentido de impor ao mundo as 'regras' da globalização neoliberal: a liberdade plena de circulação de capitais; a desregulamentação dos mercados de capitais, incluindo o mercado de divisas; o combate prioritário à inflação e a desvalorização das políticas de promoção do emprego; a privatização das empresas públicas, incluindo as que produzem e fornecem serviços públicos; a adoção de políticas tributárias favoráveis aos muito ricos e aos rendimentos do capital; a rejeição de qualquer ideia de equidade e de quaisquer políticas de redistribuição do rendimento em favor dos titulares de rendimentos mais baixos. Particular atenção mereceram as políticas tendentes à contenção e à redução dos salários reais e dos direitos dos trabalhadores, num mundo em que a mundialização do mercado de trabalho significou um aumento enorme do exército de reserva de mão-de-obra e constituiu um estímulo poderoso à deslocalização de empresas, em busca de mão-de-obra mais barata e sem direitos.

A reaganomics nos EUA e o thatcherismo no Reino Unido marcam, a partir de 1979, o início deste novo ciclo, em que a ideologia neoliberal se confirmou como a ideologia dominante, a ideologia das classes dominantes (mais especificamente, a ideologia do setor dominante das classes dominantes: o setor financeiro).

Em 1987, Alan Greenspan assume o comando do Sistema de Reserva Federal dos EUA, posto em que se mantém até 2006.

Por meados dos anos 1980, as grandes linhas da ideologia neoliberal começaram a dominar o pensamento e a ação dos partidos socialistas e sociais-democratas, sobretudo na Europa, talvez convencidos de que, nas condições da época, o respeito pelo deus mercado era uma condição de 'respeitabilidade' política. Os dogmas neoliberais ganharam novos crentes, que recorrentemente vêm defendendo a sua 'fé' com o inadmissivel 'argumento' thatcheriano de que não há alternativa [There is no Alternative].

A criação da União Económica e Monetária (UEM) em Maastricht (1991), com a moeda única (o euro), o Banco Central Europeu (BCE) e o Pacto de Estabilidade e Crescimento (PEC), é o ponto crítico da submissão da 'Europa' ao espírito do Consenso de Washington.

Os momentos de crise sucederam-se a partir dos anos 1980. Em 1995, a crise que teve o peso mexicano como protagonista fez tremer o sistema financeiro dos EUA e, por reflexo, o sistema financeiro de todo o mundo capitalista. 
Por essa altura, Michel Camdessus (então Diretor-Geral do FMI) escreveu que o mundo é dominado por um poder político sem controlo, à mercê de uma "classe composta por agentes globais que manipulam divisas e ações e dirigem um fluxo de capital de investimento livre, fluxo esse que todos os dias se torna mais importante, praticamente ao abrigo de todos os controlos estaduais". Referindo-se a estes especuladores profissionais, Camdessus não hesitou em afirmar, sem qualquer cerimónia, que "o mundo está nas mãos destes tipos".

E John Major, então Primeiro-Ministro britânico, observava que o jogo dos especuladores assume "dimensões que o colocam fora de qualquer controlo dos governos e das instituições internacionais". O Primeiro-Ministro italiano, Lamberto Dini, proclamava que "não se pode permitir que os mercados minem a política económica de todo um país". Mais radical foi o Presidente francês Jacques Chirac (outubro/1995): os especuladores são a "a sida da economia mundial".

Apesar deste alarme dos criadores perante o comportamento das suas próprias criaturas, a verdade é que nada foi feito para pôr cobro a esta vertigem libertária, nem sequer com o pretexto de salvar a economia mundial desta espécie de 'sida' que vai diminuindo as suas resistências. Crise após crise, a sida tomou conta da economia mundial, debilitando-a pela via do aumento do desemprego, do trabalho precário e da diminuição dos salários reais e dos direitos dos trabalhadores, do aumento da desigualdade e da exclusão social.

4. A 'guerra' entre os grandes colossos que operam no setor produtivo em mercados cada vez mais alargados e mais 'monopolizados' veio agravar as dificuldades de obter taxas de lucro atrativas nos setores não-financeiros, que vêm laborando com uma percentagem significativa de capacidade ociosa.

Por outro lado, as empresas não-financeiras tornaram-se cada vez mais dependentes dos financiamentos concedidos pela banca, que tem conseguido impor taxas de juro reais consideravelmente elevadas. E este é um dos fatores que tem 'ajudado' a avolumar as dificuldades de obtenção de taxas de lucro 'interessantes' na atividade produtiva, cujas empresas vêm apresentando níveis crescentes de endividamento e um peso crescente (às vezes insuportável) dos encargos financeiros nos custos de funcionamento. 
Com a consolidação da "contra-revolução monetarista" (anos 80 do século xx), ganhou importância relevante um dos aspetos da financeirização das economias capitalistas, que se vinha manifestando desde finais da década de 1960: o aumento acentuado do peso da participação dos investidores institucionais (bancos, companhias de seguros, fundos de investimento, fundos de pensões e mesmo alguns fundos soberanos) no capital acionista das sociedades cotadas em bolsa. ${ }^{158}$

Acresce que uma variada gama de instituições financeiras especializadas passou a gerir, em nome dos seus clientes, enormes carteiras de títulos, cuja dimensão tem aumentado exponencialmente.

Esta nova realidade significou uma mudança de comportamento dos 'investidores' em ações, contribuindo para alimentar a espiral de especulação e para a transformação definitiva das bolsas em bolsas-casino. Em 1999, os valores das novas ações emitidas através da sua venda nas bolsas de Nova York foi de cem mil milhões de dólares. Mas o valor total das ações transacionadas naquelas bolsas atingiu a cifra de 20, 4 milhões de milhões de dólares. Quer dizer: só 1\% dos valores transacionados nas bolsas representam novo capital para as sociedades cotadas em bolsa; 99\% dos negócios bolsistas são jogos de casino. ${ }^{159}$ As bolsas são a alma do capitalismo de casino (expressão que Susan Strange inventou para caraterizar o capitalismo atual).

Nos anos 1950, a regra era ainda a de que a propriedade destes ativos era mantida, nas mesmas pessoas (famílias), durante longos períodos. Atualmente, nos EUA, as ações mantêm-se na titularidade do mesmo 'investidor', em média, por um período que não vai além de um ano. As transações de ações em bolsa representavam cerca de 18\% do capital cotado em bolsa até finais de 1968. Esta percentagem estabilizou à roda dos 20\% na década de 1970, mas atingiu 102\% em 2000, prática que só pode ter-se acentuado desde então.

Novidade é também a lógica de atuação das grandes sociedades cotadas em bolsa e dos seus administradores. As perspetivas sobre a vida e o êxito das empresas a médio prazo e a longo prazo deixaram de interessar aos acionistas-

158 Tomando o exemplo dos EUA, os particulares detinham, nos anos 1950, cerca de $90 \%$ das ações das sociedades cotadas em bolsa. No final dos anos 1970, essa percentagem baixou para 59\% e em 2000 era apenas de 42\%. O resto das ações pertencia aos referidos investidores institucionais, que respondiam por cerca de $3 / 4$ das transações em bolsa. Cfr. J. CROTTY, ob. cit., 274.

159 Cfr. M. KELLY, ob. cit., 33-35. 
-investidores-especuladores (que são tudo menos empresários). Especializados na arte de "enriquecer a dormir" (na expressão de François Miterrand, há uns anos atrás), o negócio deles são os jogos de casino. A sua preocupação fundamental é a de garantir, a curto prazo, a valorização do capital acionista, passando para segundo plano a saúde económica das empresas do setor produtivo, assim transformadas em meras fichas dos jogos de casino.

O capital financeiro descobriu um modo autónomo de ganhar dinheiro, à margem (e à custa) do setor produtivo. Para tanto, as 'metas' atribuídas pelos donos do capital aos gestores profissionais das sociedades cotadas em bolsa passaram a traduzir-se na garantia de elevados rendimentos financeiros a curto prazo e na distribuição pelos acionistas-investidores dos máximos dividendos possíveis em cada exercício. Este é um caminho que privilegia a ótica do curto prazo e desvaloriza a ótica de médio e longo prazos, uma lógica que pode ajudar a compreender o fenómeno de 'desindustrialização' que se vem registando, perigosamente, nos EUA e na Europa.

Em certas condições, tais resultados só são possíveis através do recurso sistemático à fraude em grande escala, através da falsificação dos balanços e da difusão de informação viciada, práticas criminosas que estiveram na ordem do dia no último quarto de século, dando origem (quando conhecidas...) a enormes escândalos, que vieram desfazer o mito da transparência, da racionalidade e da eficiência dos mercados financeiros regulados e afetaram negativamente a honorabilidade das mais 'distintas' empresas de contabilidade e de consultadoria financeira (basta recordar a Arthur Anderson, que desapareceu com o escândalo da ENRON) e das 'sagradas' agências de rating, todas elas comprometidas até à medula com as instituições financeiras e com os gestores das grandes empresas neste jogo de falsidades. ${ }^{160}$

Os gestores profissionais passaram a ter interesse direto na instrumentalização das empresas que gerem ao serviço dos especuladores, entre os quais se incluem. Com efeito, eles são pagos em função dos resultados obtidos no cumprimento das metas fixadas pelos grandes acionistas-investidores-especuladores,

160 Nos EUA, o Congresso, alertado para a situação, nada fez para pôr cobro à fraude, porque "as indústrias financeiras e de contabilidade estão entre os maiores contribuintes para as campanhas dos políticos de Washington, numa época em que as eleições são obscenamente caras". (J. CROTTY, ob. cit., 276) 
maximizando os ganhos financeiros a curto prazo. E são pagos (ordenados e prémios), em grande parte, mediante a entrega de ações das sociedades que administram. ${ }^{161}$

Há alguns anos atrás (ao longo da década de 1970) a doutrina dominante garantia que os top managers não serviam a lógica do capital, gerindo as empresas dotadas de alma como verdadeiros servidores do interesse público. Proclamou-se mesmo que esta revolução dos gerentes tinha transformado o capitalismo em socialismo, anulando o socialismo como alternativa ao capitalismo. Pois bem. Os gerentes deixaram de ser 'revolucionários', e, como grandes acionistas-investidores-especuladores, apostam agora, por todos os meios (incluindo as práticas criminosas), na obtenção de ganhos de capital a curto prazo, associados à especulação bolsista. E o estado ajuda, tornando o 'jogo' mais atraente: as mais-valias ganhas na bolsa ou não são tributadas ou pagam impostos muito inferiores aos que incidem sobre os lucros da atividade produtiva.

Envolvidas nesta teia de interesses especulativos, as empresas dos setores não-financeiros deixaram de se autofinanciar (com uma parte dos lucros não distribuídos), e, muitas vezes, são 'empurradas' para situações de sobreendividamento (o que aumenta a conta dos juros a pagar à banca) para que os seus gestores possam falsificar os balanços e manipular os 'mercados'. E os dividendos que distribuem prodigamente por acionistas (incluindo bancos e outras instituições financeiras) e gestores vão direitinhos para a especulação financeira (preferencialmente em paraísos fiscais, para manter o 'segredo dos negócios' e fugir ao fisco). À escala mundial, é este também o destino de excedentes de capital que não encontram no setor produtivo oportunidades de investimento tão lucrativo como a especulação financeira.

Assim se alimenta o processo de financeirização, a subordinação do capital produtivo ao capital financeiro puramente especulativo. Em última instância, a lógica do capital financeiro privilegia a obtenção de ganhos da especulação a curto prazo e desvaloriza os planos de investimento a médio prazo e a longo prazo, ficando em causa o financiamento adequado do investimento produtivo e da inovação, com a consequente menor criação de emprego e maior pressão

161 Segundo dados colhidos em J. CROTTY (ob. cit., 274), os honorários dos top managers aumentaram, nos EUA, mais de 300\% entre 1970 e 1999, período durante o qual a parte paga em ações da própria empresa passou de $22 \%$ para $63 \%$. 
para cortar nos custos salariais, na tentativa de compensar o aumento dos encargos financeiros das empresas.

5. Entretanto, o processo de inovação financeira continuou a fazer o seu caminho, sem qualquer controlo.

A progressiva liberalização e desregulamentação dos mercados financeiros, juntamente com a absoluta liberdade de circulação de capitais, abriram de par em par as portas da especulação e a especulação ameaça afundar a economia, à escala mundial, como é próprio deste mundo 'globalizado'.

Sabe-se hoje que os receios de uma crise financeira mundial já tinham chegado à reunião do G7 de fevereiro/2007. Nela foi abordada a eventual necessidade de regulamentar a atividade dos chamados hedge funds. Estes são fundos de investimento puramente especulativos, inteiramente desregulados, que operam à escala mundial, muitas vezes com sede em off-shores, que escapam às regras da transparência e ao controlo das autoridades de supervisão, atuando com base em estratégias de investimento que buscam a máxima rentabilidade investindo em 'produtos' de alto risco. Constituem, por tudo isso, elementos fortemente desestabilizadores do sistema financeiro e propagadores de elevado potencial das crises financeiras.

Os mais avisados já então admitiam que o colapso de um deles poderia arrastar consigo uma crise mundial de grandes dimensões. Mas os 'donos' do 'casino' (com destaque para os EUA e o Reino Unido, que constituem o ninho acolhedor de cerca de dez mil hedge funds) opuseram-se a qualquer intervenção. A roleta continuou a rodar, até que a crise rebentou. ${ }^{162}$

Os apóstolos das liberdades do capital sempre proclamaram, aliás, o seu carinho por estes fundos de investimento geradores de "altos lucros financeiros", capazes de atrair "um grande aparato de pessoas e de instituições altamente qualificadas". E Alan Greenspan - que vimos citando - sublinha que "as estratégias

162 Reunindo dados de Van Hedge Fund Advisors International, Inc. (colhidos em http://www. hedgefund.com), J. M. QUELHAS (ob. cit., 516) mostra que no período entre 1988 e 2002, o número de hedge funds aumentou de 1373 para 7500, passando o valor dos ativos geridos por estes fundos, no mesmo período, de 42 mil milhões de dólares para 650 mil milhões de dólares. Esta tendência não abrandou, pelo menos até finais de 2007. 
de investimento dos hedge funds continuam a ser úteis para a eliminação de spreads anormais nos mercados e, talvez, até para a superação de muitas ineficiências".

O gurú do neoliberalismo sabe que nem sempre a realidade sustenta o seu otimismo. Cita mesmo o caso de um dos mais 'ilustres' destes fundos, cujos administradores (entre os quais dois economistas americanos galardoados com o Prémio Nobel da Economia) "se transformaram em jogadores compulsivos, fazendo grandes apostas que tinham pouco que ver com o seu plano de negócios original". Resultado: "Em 1998, a LTCM [o tal hedge fund] perdeu as calças" (a expressão é de Greenspan), sendo os prejuízos absorvidos por empresas seguradoras, fundos de pensões e instituições semelhantes. ${ }^{163}$

Apesar disso, Greenspan regozija-se pelo facto de que tais fundos "não estão sujeitos a qualquer regulamentação pelo estado", fazendo votos para que continuem assim, porque, segundo ele, "os hedge funds ["vibrante setor trilionário, dominado por empresas americanas"] e os fundos de private equity parecem representar as finanças do futuro".

Para salvaguarda do futuro, Greenspan insiste em que "qualquer restrição normativa às estratégias e às táticas de investimento dessas entidades limitaria a assunção de riscos, que é parte integrante da contribuição dos hedge funds para a economia global e, principalmente, para a economia dos Estados Unidos. Por que circunscrever o voo das abelhas polinizadoras de Wall Street?”, pergunta ele.

O esforço 'teorizador' de Greenspan continua: "A inovação é tão importante para nossos mercados financeiros globais quanto para a tecnologia, para os bens de consumo e para a assistência médica. Para acompanhar a expansão da globalização, o nosso sistema financeiro precisa de manter a sua flexibilidade. O protecionismo [i. é, a regulamentação], qualquer que seja o pretexto, político ou económico, seja qual for o seu impacto sobre o comércio ou sobre as finanças, é receita certa para a estagnação económica e para o autoritarismo político". ${ }^{164}$

O Sr. Alan Greenspan, o grande apóstolo da desregulamentação (que se define a si mesmo como "defensor ferrenho do livre funcionamento dos mercados"165),

163 Cfr. A. GREENSPAN, A Era..., cit., 357-359.

164 Cfr. A. GREENSPAN, A Era..., cit., 363. Levando a sério as considerações de Greenspan, teríamos de concluir que Reagan, G. W. Bush (e talvez até Pinochet) e os seus Governos foram exemplos de democracia.

165 Cfr. A. GREENSPAN, A Era ..., cit., 359. 
sempre defendeu, como Presidente do FED, que quanto mais liberdade para o capital financeiro melhor para os negócios (e melhor para o mundo). O seu estímulo e o seu aplauso como 'papa' do mundo financeiro facilitaram a revogação (em 1999) do Glass-Steagall Act, deixando os bancos livres para a especulação. ${ }^{166}$ A onda liberalizadora e desregulamentadora abriu as portas do casino aos bancos, e estes, como jogadores compulsivos, 'queimaram' no jogo, criminosamente, o dinheiro dos depositantes.

As suas responsabilidades foram-lhe recordadas numa Comissão do Congresso, perante a qual, já em plena crise, Greenspan prestou declarações. "O senhor disse-lhe o Presidente da Comissão - tinha autoridade para evitar práticas irresponsáveis que conduziram à crise dos empréstimos subprime. Foi avisado por muita gente para atuar nesse sentido. Agora a nossa economia como um todo está a pagar o preço". ${ }^{167}$

Na sequência do interrogatório, o Congressista recordou afirmações públicas de Greenspan defendendo as teses mais fundamentalistas do neoliberalismo: "não é necessária qualquer regulação pública", mesmo quando se trata de "transações de produtos derivados fora de bolsa", porque "nada na regulação levada a cabo pelo estado a torna superior à regulação do mercado”. E perguntou-lhe se se sentia pessoalmente responsável pelo que aconteceu. Greenspan não respondeu diretamente e o Presidente da Comissão continuou a citá-lo: "Eu tenho uma ideologia. O meu juízo é que mercados livres e de concorrência são, de longe, o melhor modo de organizar as economias. Tentámos as regulações. Nenhuma delas funcionou minimamente". Como quem diz: eu tenho uma ideologia e atuei em conformidade com ela, porque só o mercado livre resolve os problemas.

Foi a vez de o Congressista insistir: "O senhor acha que a sua ideologia o empurrou para tomar decisões que o senhor gostaria de não ter tomado? (...) O senhor enganou-se?" Resposta de Greenspan: "Eu cometi um erro ao presumir que os interesses próprios de organizações, especificamente bancos e outras, eram tais que constituíam o modo mais capaz de proteger os seus próprios acionistas e as suas ações nas empresas. (...) Na realidade, um pilar crítico da concorrência e do mercado livre quebrou. E penso que isso me chocou. Ainda não compreendi

166 Cfr. A. GREENSPAN, A Era..., cit, 362/363.

167 As citações relativas a esta sessão no Congresso dos EUA foram colhidas em J. CASSIDY, ob. cit., 4-6. 
inteiramente porque é que isso aconteceu, e, obviamente, na medida em que eu veja claro o que aconteceu e porquê, eu mudarei os meus pontos de vista".

Em outro momento das suas declarações, Greenspan afirmou: "Encontrei uma falha no modelo que eu considerava como a estrutura crítica de funcionamento que define o modo como o mundo funciona, se posso dizer assim”. Tentando concluir, o Presidente da Comissão interpelou Greenspan: "Por outras palavras, o senhor acha que a sua concepção do mundo, a sua ideologia, não era correta”? Ao que Greenspan respondeu: "Precisamente". Mas não deixou de salientar que ter uma ideologia é, a seu ver, uma condição indispensável para lidar com a realidade e que, para existir, precisamos de uma ideologia ("To exist, you need an ideology").

É um diálogo curioso e elucidativo. Ele mostra que se entregou à raposa a guarda da capoeira, confiando a regulação ao defensor mais radical da desregulação. Ele mostra também quanto é urgente uma reflexão séria sobre esta problemática por parte de todos aqueles que, à 'esquerda', em nome do pragmatismo, da 'modernidade', da 'respeitabilidade' como políticos capazes de bem gerir o capitalismo, vêm procurando apagar a ideologia (com o argumento TINA de que não há alternativa...), aceitando, como 'comandos' inevitáveis, os dogmas da ideologia neoliberal.

Como se diz atrás, há anos que os especialistas na matéria chamam a atenção dos responsáveis políticos para o perigo de os novos produtos financeiros, nomeadamente os produtos derivados, se transformarem em "armas de destruição maciça”. O 'desregulador-mor' não ignorava estes estudos. Mas, como todos os grandes do mundo, há-de ter pensado que, nas guerras, quem costuma morrer é o povo...

O que é verdade é que nas cimeiras do G20 de 2008 (Washington) e de 2009 (Pittsburg) se falou da necessidade de reforçar os mecanismos de regulação e de supervisão do setor financeiro. Mas não se foi além da conversa. ${ }^{168}$ Quando o 'negócio' faliu, chamaram o povo para os salvar, e o povo está a pagar a fatura.

No Relatório da Comissão de Inquérito à Crise Financeira, entregue ao Presidente Obama em janeiro/2011, reconhece-se que, antes de a crise rebentar, não faltaram os sinais anunciadores dela, sinais que foram ignorados ou mini-

168 Informação colhida no chamado Relatório Podimata, cit., 5. 
mizados. O FED nada fez para impedir os bancos de conceder empréstimos de alto risco, deixando-os, irresponsavelmente, 'envenenar-se' com ativos tóxicos: "os reguladores tinham o poder necessário para proteger o sistema financeiro", mas "escolheram não o utilizar", diz o Relatório. Nele se denunciam as pressões das instituições financeiras sobre os decisores políticos e sobre as entidades reguladoras, feitas à custa de milhares de milhões de dólares pagos às sociedades de lobbying e pagos aos políticos para financiar as suas campanhas eleitorais. A ação das agências de rating é igualmente apontada como um dos fatores essenciais da crise. ${ }^{169}$

Hoje é por demais evidente a pesada responsabilidade desta política neoliberal de fomento e garantia das liberdades do capital financeiro no desencadear da grave crise financeira que anunciou e desencadeou a crise económica profunda e global que hoje se vive no mundo capitalista: a progressiva desregulamentação dos mercados financeiros, a liberdade absoluta de circulação de capitais à escala mundial e a deficiente (ou cúmplice) atuação das entidades reguladoras e das sociedades (privadas) de rating são alguns dos fatores que conduziram o 'casino' à bancarrota.

Esta crise veio tornar evidentes as consequências dramáticas do capitalismo de casino, da predominância do capital financeiro sobre o capital produtivo, do corte entre a especulação financeira e a economia real, pondo em xeque, de modo irrecusável, os cânones do neoliberalismo.

6. Uma das mais celebradas invenções da 'inovação financeira' é a titularização de créditos, cuja importância cresceu exponencialmente a partir do início da década de 2000 (em 2007, o valor envolvido correspondia a pouco menos de metade do produto mundial), fazendo dela um dos instrumentos da financeirização do sistema capitalista, que se acentuou a partir dos anos 80 do século xx.

A titularização de créditos está na base da crise financeira que começou nos EUA no setor do crédito hipotecário. Vendiam-se habitações a crédito (garantido por hipoteca sobre o prédio vendido) a quem não tinha capacidade financeira

169 Cfr. Le Monde Diplomatique (ed. port.), março/2011, 8. Tem inteira razão Serge Halimi: "os responsáveis políticos comportam-se demasiadas vezes como marionetas que se preocupam, sobretudo, em não incomodar o festim dos banqueiros" (Le Monde Diplomatique, maio/2011, 1). 
para as pagar e a quem as comprava apenas com fins especulativos (ganhar, a curto prazo, com a valorização dos imóveis). De seguida, emitiam-se novos títulos obrigacionistas, assentes na hipoteca.

Falam alguns autores de financeirização do rendimento pessoal dos indivíduos ou famílias que recorriam ao crédito bancário (para a compra de casa, mas também para a educação, a saúde, etc.), com o objetivo de extrair dele, diretamente, um ganho financeiro (puramente especulativo). A esta prática chama Costas Lapavitsas "expropriação financeira". ${ }^{170}$

A voragem era tal que, enquanto o preço das habitações foi aumentando, muitos dos clientes dos bancos que tinham adquirido as suas casas a crédito eram encorajados a constituir sobre elas uma nova hipoteca, para receberem mais crédito ao consumo, que iria ser igualmente titularizado, numa espiral vertiginosa.

A banca começou a vender pacotes desses produtos derivados (títulos obrigacionistas negociáveis), assentes em créditos hipotecários menos fiáveis, 'produtos' que foram adquiridos por investidores institucionais (nomeadamente os atrás referidos hedge funds), tendo-se espalhado por instituições financeiras de todo o mundo. Disperso o risco pela grande quantidade de titulares de unidades de participação nestes fundos, os inventores deste 'jogo' talvez tenham pensado ter resolvido a quadratura do círculo, acreditando que poderiam vender sem limitações esses créditos titularizados, com base na ilusão de que a dispersão dos riscos os fazia desaparecer. ${ }^{171}$

O dinheiro disponível excedia a capacidade de investimento na economia real, pelo que os grandes gestores da banca se convenceram de que podiam ganhar muito dinheiro emprestando-o ou lançando-o no 'jogo' sem acautelar minimamente o seu reembolso. E, se bem o pensaram, melhor o fizeram: alguns bancos chegaram a emprestar o equivalente a trinta vezes o montante dos seus depósitos. Para tanto, montaram um 'esquema' assente nos chamados empréstimos subprime, assim designados porque concedidos sem respeitar as regras técnicas sobre as garantias exigidas a quem recorre ao crédito, no que toca à sua capacidade para cumprir atempadamente os encargos da dívida (juros e amortização do capital). Muitos desses empréstimos foram, aliás, designados

170 Cfr. C. LAPAVITSAS, "Financialised Capitalism", op. cit., p. 115.

171 A verdade é que, no período entre 2004 e 2006, foram titularizados 79, 3\% destes créditos hipotecários de baixa qualidade. Cfr. C. LAPAVITSAS, últ. ob. cit., 117. 
empréstimos tipo ninja, i. é, empréstimos concedidos a quem não tinha rendimentos, nem emprego, nem ativos - "No Income, no Job or Asset". ${ }^{172}$

Num país em que o endividamento das famílias, graças ao 'estímulo' do crédito ao consumo, representa $120 \%$ do rendimento disponível, a fantasia desfez-se quando, em meados de 2006, os preços das habitações começaram a baixar e, no primeiro trimestre de 2007, cerca de $15 \%$ das pessoas (famílias) que tinham sido atraídas pelo crédito fácil deixaram de pagar os seus encargos (mais de dois milhões de famílias). Foi o início da subprime crisis, com a falência do subprime market, no qual se negociavam produtos financeiros derivados do crédito de baixa qualidade concedido a empresas de construção civil e a compradores de casa (subprime credit).

Já em 2004 o próprio FBI chamava a atenção, publicamente, para o que designava "uma epidemia de fraudes hipotecárias". As entidades reguladoras fizeram de conta que não viam nada e a Administração de George W. Bush não só não fez nada como deu a entender, com suficiente clareza, que nada faria. ${ }^{173}$

O risco afetou rapidamente não só os bancos mas também as companhias de seguros que tinham feito o seguro (e até o resseguro) dos créditos concedidos, bem como os fundos de investimento controlados por aqueles, cujas dificuldades aumentaram porque o valor de mercado dos prédios hipotecados foi baixando progressiva e acentuadamente (entre 5\% e 10\% em 2007; em maior escala ainda em 2008), por excesso de oferta e baixa da procura. Quando os produtos derivados resultantes da titularização dos créditos hipotecários, embora teoricamente negociáveis, deixaram de ser negociados na prática, porque ninguém os queria,

172 Um exemplo esclarecedor da fúria especulativa, à margem das regras mais elementares das práticas bancárias, é relatado por Richard Cohen em The Washington Post, tendo como personagem a Sra Marvene Halterman, de Avondale, Arizona. "Aos 61 anos, após 13 anos desempregada e pelo menos outros tantos vivendo da previdência social, ela conseguiu uma hipoteca. Conseguiu-a apesar de, em certa ocasião, viverem 23 pessoas em sua casa (175 metros quadrados, uma casa de banho) e em algumas edículas caindo aos pedaços. Ela conseguiu pelo imóvel 103 mil dólares, quantia que excedia em muito o valor da casa. (...) A casa da $\mathrm{Sr}^{\mathrm{a}}$ Halterman nunca fora exatamente uma vitrine - uma vez fora intimada pela prefeitura por causa de todo o entulho (roupas, pneus, etc.) no quintal. Contudo, uma instituição financeira local, com o nome de fachada Integrity Funding $L L C$, deu-lhe uma hipoteca, avaliando a casa em cerca do dobro do preço pelo qual uma propriedade vizinha semelhante fora vendida... A Integrity Funding vendeu depois à Wells Fargo E Co., que o vendeu ao HSBC Holding PLC, que então o empacotou junto com milhares de outras hipotecas de risco e ofereceu o mingau indigesto a investidores. A Standard and Poor's e a Moody's Investors Service fizeram averiguações, como deveriam fazer, e atribuíram a notação triplo-A (AAA), i. é, totalmente isento de riscos" (apud James GALBRAITH, Introdução, cit., 10/11).

173 Informação colhida em James GALBRAITH, Introdução, cit., 9. 
chegou-se ao fim do caminho: a banca do 'casino' ficou sem fundos; as famílias estavam mais endividadas (muitas perderam as casas) e as taxas de poupança baixaram dramaticamente. ${ }^{174}$

Em pouco tempo a crise instalou-se no mercado interbancário, o mercado em que os bancos emprestam dinheiro uns aos outros, em regra a prazos muito curtos. Perante a realidade, os bancos deixaram de confiar uns nos outros (porque conheciam bem o lixo que todos tinham acumulado) e deixaram de conceder crédito uns aos outros, o que provocou a diminuição da liquidez, a escassez do crédito e o aumento das taxas de juro.

Em março de 2008, o Bear Sterns (um importante banco de investimentos) entrou em colapso, tendo sido salvo pelo FED, que forçou a sua compra pelo JPMorgan, ao qual teve de conceder, para esse efeito, um empréstimo de 29 mil milhões de dólares. Em 7 de setembro de 2008, o governo americano 'tomou conta' da Fannie Mae e da Freddie Mac (as duas 'estrelas' do crédito hipotecário, que detinham cerca de metade do mercado dos créditos hipotecários), numa operação de salvamento que custou aos contribuintes americanos 200 mil milhões de dólares.

Na tentativa de aumentar a liquidez, o FED injetou milhões de dólares no circuito financeiro, gastou um milhão de milhões de dólares na compra de ativos tóxicos e ofereceu crédito a taxas de juro próximas de zero. Apesar disso, o Lehman Brothers anunciou falência no dia 15 de setembro de 2008. No dia seguinte, a Administração americana decidiu intervir (transformando dívida privada em dívida pública) para salvar o AIG (American International Group), um grupo segurador de créditos, muitos deles assentes em ativos tóxicos. ${ }^{175}$

Por pressão do capital financeiro, o estado capitalista, fiel aos dogmas do neoliberalismo, concedeu todas as liberdades à especulação. Quando o 'negócio' faliu, foi chamado o estado para salvar os especuladores, tendo respondido à chamada com toda a solicitude e determinação, convocando o povo para pagar a fatura. Só os acionistas e os credores do Lehman Brothers perderam o seu dinheiro. Invocando o risco sistémico (que até então ignorara), a Administração

${ }_{174}$ De 9\%/10\% do rendimento disponível nos anos 1970/1980, a taxa de poupança das famílias baixou para 0, 4\% em 2006/2007. Cfr. C. LAPAVITSAS, últ. ob. cit., 118.

175 Segundo a chamada Doutrina Greenspan, as bolhas não podem ser prevenidas, cabendo ao estado resolver o problema a posteriori. E "a prática de Greenspan foi criar uma bolha após outra, até finalmente surgir uma tão vasta que destruiu todo o sistema". Cfr. James GALBRAITH, Introdução, cit., 9/10. 
de G. W. Bush anunciou que não deixaria falir mais bancos, protagonizando a mais dispendiosa intervenção do estado na economia desde os anos trinta, apesar de sempre ter proclamado que a intervenção do estado na economia era uma das marcas do império do mal. Estava inventado o capitalismo sem falências, ao menos para os bancos (e outras instituições financeiras) considerados too big to fail. ${ }^{176}$ As voltas que o mundo dá.... No final de 2008, a crise financeira degenerou em crise económica, que teve o momento mais simbólico no afundamento da General Motors, o símbolo da indústria americana e do poderio americano (ficou célebre o slogan: o que é bom para a GM é bom para os EUA), salva à custa de milhões e milhões de dólares saídos dos bolsos dos contribuintes.

7. Parece até que, desta vez, tudo foi planeado para que a crise acontecesse. Num artigo publicado em L'Express em finais de 2011, até o insuspeito Jacques Attali vem reconhecer que "esta crise foi consequência do enfraquecimento da parte dos salários no valor acrescentado". ${ }^{177}$ Mas a importância do "enfraquecimento da parte dos salários no valor acrescentado" como elemento potenciador de crises de sobreprodução é de há muito conhecida. Marx esclareceu esta questão. E Keynes, à sua maneira, deixou claro que as enormes desigualdades de rendimento não favoreciam o crescimento económico, antes provocariam a insuficiência da procura efetiva, que ele considerava a causa das crises cíclicas próprias do capitalismo.

E, no entanto, a tentativa de travar a tendência para a baixa das taxas de lucro (que a crise de 1973-1975 evidenciara) conduziu, nas últimas décadas, à adoção de políticas sistemáticas de diminuição da parte dos salários no rendimento global e do poder de compra dos salários, apesar de se saber que estas políticas potenciam a ocorrência de crises.

7.1. O pensamento liberal sempre assumiu que a baixa dos salários reais é o elemento indispensável para tornar atrativa a contratação de trabalhadores desempregados e assim inverter o ciclo, abrindo o caminho para que, com base

\footnotetext{
176 Cfr. G. STERN and R. FELDMAN, Too Big to Fail, ob. cit.

177 Citado por A. BARROSO, ob. cit., 16.
} 
no funcionamento do mercado livre, se atinjam situações de reequilíbrio com pleno emprego em todos os mercados e em todos os setores da economia.

Hayek enfatiza este ponto: "o problema do desemprego é um problema de salários". Isto é: a diminuição dos salários reais e salários reais baixos são a condição indispensável e decisiva para se prevenirem e se ultrapassarem as crises, que poderiam ser evitadas se se deixassem funcionar livremente os mercados, nomeadamente o mercado de trabalbo, liberto das 'imperfeições' que o descaraterizam (contratação coletiva, salário mínimo garantido, proteção legal contra os despedimentos sem justa causa, subsídio de desemprego, etc.).

Compreende-se, por isso, que, ao longo das últimas quatro décadas de império neoliberal, os interesses e os atores que estão por detrás da financeirização tenham pressionado (e continuem a pressionar) os governos a adotar as políticas de arrocho salarial (diminuição dos salários reais e diminuição da parte da riqueza criada que cabe aos trabalhadores), bem como as políticas que dão primazia ao combate à inflação (para não ficarem em risco as cotações dos valores mobiliários) e que desvalorizam a promoção do crescimento e do emprego. ${ }^{178}$

Num contexto de acentuado desenvolvimento científico e tecnológico (rapidamente incorporado na atividade produtiva) e consequente aumento da produtividade, tratava-se de fazer reverter os ganbos da produtividade em benefício do capital, impedindo os trabalhadores de beneficiar condignamente da riqueza que criam. ${ }^{179}$

7.2. Em termos globais, a produtividade aumentou, à escala mundial, nos últimos dez anos, cerca de 30\%, enquanto o aumento dos salários não foi além de 18\%.

178 Cfr. P. - A. IMBERT, ob. cit., e M. HUSSON, ob. cit.

179 Hayek condenou violentamente a pretensão dos sindicatos de que os salários devem aumentar tendo em conta os aumentos da produtividade, pretensão hoje geralmente considerada socialmente justa e economicamente vantajosa, de tal modo que mesmo as associações patronais não a atacam em público, por acreditarem que tal seria 'politicamente incorreto'. Para Hayek ao invés, a aceitação daquela pretensão dos sindicatos equivaleria ao reconhecimento do direito de expropriar uma parte do capital das empresas. Vejamo-lo nas suas próprias palavras: "O reconhecimento do direito do trabalhador de uma empresa de participar, enquanto trabalhador, numa quota dos lucros, independentemente de qualquer contribuição que ele tenha feito para o seu capital, faz dele proprietário de uma parte da empresa. Neste sentido, tal exigência é, sem dúvida, puramente socialista e, o que é mais, não baseada em qualquer teoria socialista do tipo mais sofisticado e racional, mas no mais grosseiro tipo de socialismo, vulgarmente conhecido por sindicalismo." Cfr. F. HAYEK, "Unions..., cit., 281ss. 
A 'globalização' aumentou enormemente o número de trabalhadores disponíveis à escala mundial, tendo o exército de reserva de mão-de-obra aumentado também, no quadro europeu, na sequência da implosão da URSS, do desaparecimento da comunidade socialista europeia e da integração de vários dos países da Europa central e de leste na própria União Europeia.

Os especialistas põem em relevo o facto de que "os trabalhadores de todos os países, independentemente do seu grau de desenvolvimento industrial e do sistema social, estão doravante em concorrência entre si, em todos os domínios da economia, com um leque salarial entre um e 50 ou mais". O aumento da concorrência entre os trabalhadores neste novo mercado mundial do trabalho já foi considerado "a principal consequência social da mundialização". 180 Ele é, sem dúvida, um elemento novo na caraterização do capitalismo global, que não existia em 1916, quando Lenine publicou o estudo clássico sobre O Imperialismo, e que precisa de ser analisado à luz da revolução científica e tecnológica do último quarto de século.

Nestas condições particularmente favoráveis ao capital, o referido objetivo foi plenamente conseguido. O aumento da parte do capital na partilha do valor criado pelo trabalho produtivo atingiu mesmo proporções escandalosas. A distorção, em favor do capital, da chamada distribuição funcional do rendimento tem-se traduzido no agravamento da exploração e no empobrecimento relativo (e mesmo absoluto) da grande massa dos trabalhadores, tanto nos chamados 'países ricos' como nos ditos 'países pobres.' ${ }^{181}$

180 Cfr. D. GALLiN, ob. cit., 103.

181 Os trabalhadores continuam, por outro lado, a pagar um dramático "imposto de sangue" (Ignacio Ramonet, Le Monde Diplomatique, ed. port., Junho/2003), traduzido no elevado número de vítimas de acidentes de trabalho e de doenças profissionais. Segundo dados da OIT, todos os anos 270 milhões de trabalhadores são vítimas de acidentes de trabalho e 160 milhões contraem doenças profissionais. Os acidentes de trabalho provocam todos os dias pelo menos 5 mil mortos (mais de dois milhões por ano!). Mesmo num país como a França, todos os anos morrem 800 trabalhadores vítimas de acidentes de trabalho, registando-se cerca de dez feridos por minuto.

Um Relatório da OIT elaborado no âmbito do Dia Mundial da Segurança e Saúde no Trabalbo (28.4.2010) refere que o stress, enquanto doença profissional, atinge gravemente mais de $20 \%$ dos trabalhadores da UE, sendo a causa de mais de metade dos dias de trabalho perdidos.

Neste mundo antropofágico, em estado de guerra civil permanente, há ainda que contabilizar os que morrem de fome e outras vítimas da fome. Há pouco tempo, o Prof. Jean Ziegler, membro do Comité Consultivo do Conselho de Direitos Humanos da ONU, tornava público que, de 5 em 5 minutos, morre uma criança com menos de dez anos; que mil milhões de pessoas são subalimentadas; que todos os dias morrem 47 mil pessoas de fome (Cfr. Público, 4.4.2010). Se a estes juntarmos os que morrem de doenças evitáveis, muitas vezes resultantes da fome, o número de mortos provocados por esta guerra civil é, em cada ano, muito próximo dos mortos causados pela Segunda Guerra Mundial. Este mundo capitalista, agora gerido pela cartilha neoliberal, não é, de verdade, o paraíso... 
Um estudo do FMI, publicado em 2007, mostra que a parte do rendimento do trabalho no rendimento nacional baixou, de forma sistemática, entre 1980 e 2005, no conjunto dos países mais desenvolvidos. ${ }^{182}$

No Relatório sobre o Trabalbo no Mundo/2008, a OIT sublinha que "em 51 dos 73 países para os quais existem dados disponíveis, a parte dos salários no rendimento nacional tem diminuído ao longo dos últimos vinte anos", especificando que "o declínio mais forte da parte dos salários no PIB teve lugar na América Latina e nas Caraíbas (-13 pontos percentuais), seguindo-se a Ásia e o Pacífico (-10 pontos percentuais) e as economias desenvolvidas ( 9 pontos percentuais)".

Um documento de trabalho apresentado na reunião de julho de 2010 do Banco de Pagamentos Internacionais faz uma longa análise crítica deste mesmo fenómeno: "A parte dos lucros é hoje invulgarmente elevada, e a parte dos salários invulgarmente baixa. De facto, a dimensão desta evolução e o leque dos países a que diz respeito não têm precedentes nos últimos 45 anos".

Para o conjunto da UE, a Comissão Europeia regista uma diminuição da parte dos salários de 8, 6\% entre 1983 e 2006 (9, 3\% na França). E, para o conjunto dos países do G7, o FMI aponta, para o mesmo período, uma diminuição de 5, 8\%.

Os dados oficiais mostram que, na UE/15, a parte dos rendimentos do trabalho no rendimento nacional passou de 65\% em 1980 para 49, 4\% em 2005 e 48, 9\% em 2008. Tomando a UE/25, essa percentagem passou de 50, 2\% em 2002 para 48, 5\% em 2008, sabendo-se que, em vários países da UE, entre os quais Portugal, esta percentagem é ainda mais baixa. ${ }^{183}$

Em finais de 2007, alguém tão insuspeito como Alan Greenspan reconhecia que "a parte dos salários no rendimento nacional nos EUA e em outros países desenvolvidos atingiu um nível excepcionalmente baixo segundo os padrões históricos, ao invés da produtividade, que vem crescendo sem cessar." E não escondeu a sua preocupação, invocando que "esta desproporção entre fracos níveis salariais e lucros historicamente muito elevados faz temer um aumento da

182 Cfr. IMF, Finance and Development, junho/2007.

183 Em Portugal, a distribuição mais favorável aos trabalhadores registou-se em 1975: a parte dos rendimentos do trabalho no rendimento nacional atingiu então 59\% (uma cifra modesta, apesar de bastante melhor do que a registada até 1974, durante o salazarismo); em 2002, essa percentagem rondava os 50\%, tendo-se reduzido para 47, 0\% em 2008. De então para cá, baixou e muito. 
animosidade contra o capitalismo e o mercado, tanto nos EUA como em outras zonas do mundo". ${ }^{184}$

É capaz de ter razão. Mas é curioso que Greenspan não tenha sequer aludido ao risco de uma crise grave do capitalismo, como consequência do fenómeno que regista. Talvez porque ele é um fiel da Lei de Say e acredita que as crises de sobreprodução não são possíveis nas sociedades capitalistas...

7.3. Isto significa que os ganhos da revolução científica e tecnológica têm servido, essencialmente, para aumentar os lucros (em especial os lucros especulativos do capital financeiro), quando deveriam ter ajudado à progressiva libertação dos trabalhadores, não só através do aumento dos salários, mas, sobretudo, proporcionando garantias mais sólidas no que toca aos direitos no âmbito da segurança social, melhores condições de vida e de trabalho, redução do horário de trabalho, melhores serviços públicos de educação e de saúde, universais, gerais e gratuitos.

A história do capitalismo adulto mostra que, quando o medo do aumento da "animosidade contra o capitalismo e o mercado" (A. Greenspan) perturbou o sono dos senhores do mundo, estes cederam às reivindicações dos trabalhadores, acreditando que assim os desviavam dos caminhos da revolução anti-capitalista, podendo, por isso, dormir em paz.

E mostra também que o aumento do poder de compra dos trabalhadores (que constituem a grande maioria da população) acompanhou sempre os períodos de crescimento económico e de progresso social. Isto quer dizer que a subida dos salários reais, em resultado da luta das organizações dos trabalhadores, tem constituído, historicamente, um fator de desenvolvimento pelo menos tão importante como o desenvolvimento científico e tecnológico (e o consequente aumento da produtividade), as exportações e o investimento direto estrangeiro.

O grande mérito de Keynes poderá ter residido na sua capacidade de compreender isto mesmo. E, preocupado, acima de tudo, em salvar o capitalismo, fez propostas que estão na base do estado social e do estado-providência.

184 Cfr. Financial Times, 17.9.2007. 
Mas, com a implosão da URSS e da comunidade socialista europeia, a contra-revolução monetarista ganhou novo fôlego, o pensamento único conquistou mais adeptos, a ideologia neoliberal acentuou o seu domínio, e os 'donos' do mundo acreditaram que não havia razão para medos e que, como os vampiros, poderiam comer tudo e não deixar nada.

Sempre tem sido assim: quando as condições objetivas permitem alimentar o sonho de que o capitalismo tem garantida a eternidade, ganha força a tentação reacionária de regressar ao século xvıı e à violência das relações industriais que marcou os primeiros tempos do capitalismo.

Este o sentido das políticas neoliberais - prosseguidas por conservadores, socialistas ou sociais-democratas -, que rejeitaram ou esqueceram a lição de Keynes e apostaram na baixa dos salários reais e na partilha dos ganhos de produtividade em benefício do capital. Estas políticas garantem lucros (e muitos) a curto prazo aos que "vivem do lucro" (para usar a expressão de Adam Smith), mas agravam as contradições dentro do capitalismo como um todo e acentuam os riscos de ocorrência de crises cíclicas. Em obediência aos dogmas do neoliberalismo, semearam ventos; os povos sofrem agora as tempestades.

8. Apesar dos enormes ganhos da produtividade do trabalho (a uma escala sem comparação com os séculos anteriores), decorrentes do desenvolvimento científico e tecnológico e da sua rápida aplicação na esfera da produção, a globalização neoliberal acentuou as desigualdades e condenou à extrema pobreza milhões de seres humanos, espalhando, como uma nódoa, a chaga da exclusão social (a "nadificação do outro", na expressão terrivelmente certeira do cineasta brasileiro Walter Salles), que é uma vergonha deste nosso tempo.

Ainda ninguém conseguiu demonstrar a existência de uma relação positiva entre a flexibilização da legislação laboral e os baixos salários, por um lado, e o aumento da 'competitividade' ou a redução do desemprego, por outro lado. A vida nega todos os dias esta pretensa relação, que não passa de uma criação da ideologia dominante. Keynes (e Marx antes dele) deixou claro que os salários sobem quando o desemprego diminui e diminuem quando o desemprego aumenta, e não o contrário. O desemprego não diminui quando os salários baixam nem aumenta quando os salários sobem, porque - defende Keynes - o nível do 
emprego (e o nível dos salários) depende de um fator externo ao mercado de trabalho: a procura efetiva.

Poucos aceitarão, por isso, que se justifiquem as políticas de baixa dos salários com o argumento de que elas são necessárias para proteger e para relançar o emprego. Elas visam apenas aumentar a parte do capital na riqueza produzida. E os resultados estão à vista, em termos de empobrecimento da grande maioria da população.

O Presidente do Banco Mundial (Robert Zoellick) escrevia, em outubro/2010: "Pela primeira vez na história, mais de mil milhões de pessoas deitam-se todas as noites com a barriga vazia". ${ }^{185}$

Num Relatório da OCDE de finais de 2011 (6 de dezembro) põe-se em relevo o facto de as desigualdades sociais terem aumentado ininterruptamente ao longo dos últimos trinta anos, tendo atingido níveis de rotura: "o contrato social está a desfazer-se em muitos países", recordou o Secretário-Geral daquela Organização, durante a sessão de apresentação do relatório, em Paris.

Segundo dados do FMI (outono/2010), as políticas neoliberais destruíram, em 2009, à escala mundial, 30 milhões de postos de trabalho, dando uma boa contribuição para engrossar o número dos desempregados, que rondará, segundo a OIT (Tendências Mundiais do Emprego - 2011) os 205 milhões em todo o mundo, sendo que 1530 milhões dos que têm trabalho desenvolvem a sua atividade em condições de precariedade.

Considerando pobres aqueles que auferem rendimento inferior a 60\% do salário médio do país onde vivem, 80 milhões de cidadãos da rica UE vivem abaixo do limiar da pobreza (incluindo 19 milhões de crianças), e cerca de 17\% dos europeus não têm recursos suficientes para satisfazer as suas necessidades básicas (dados da Comissão Europeia referentes a 2010).

E o Grupo de Reflexão constituído no âmbito do Conselho Europeu e presidido por Felipe González concluiu que, "pela primeira vez na história recente da Europa, existe um temor generalizado de que as crianças de hoje terão uma situação menos confortável do que a geração dos seus pais". 186

\footnotetext{
185 Citação colhida em Le Monde Diplomatique (ed. port.), outubro/2010.

186 Segundo um estudo da Fabian Society, de finais de 2009, na Inglaterra, as políticas levadas a cabo por conservadores e trabalhistas (de Thatcher a Blair e a Gordon Brown) colocaram o país "perante o risco de regressar a níveis de pobreza idênticos aos da era vitoriana" (The Independent, 30.11.2009). Também aqui, é o regresso ao século xvıII.
} 
É particularmente elucidativa, a este respeito, a análise da realidade americana a partir de 1973 (Administração Nixon) e de 1979 (com o início da reaganomics), realidade que alguém classificou como "depressão silenciosa". ${ }^{187}$

Os salários reais (que subiram sempre entre 1947 e 1973) registam uma baixa significativa a partir deste último ano. O mesmo aconteceu com o rendimento mediano das famílias americanas, sempre crescente no período atrás referido. A partir de então, este indicador só não baixou (manteve-se praticamente estagnado) porque a participação crescente das mulheres no mundo do trabalho permitiu que o salário das mulheres se somasse ao salário dos homens.

No mesmo sentido aponta a evolução registada em matéria de distribuição do rendimento: a partir do início da década de 1970 baixou o rendimento familiar médio dos $80 \%$ das famílias americanas com rendimentos mais baixos (baixas de quase $15 \%$ para os $10 \%$ mais pobres), ao mesmo tempo que aumentava (mais de $16 \%$ ) o rendimento dos $10 \%$ mais ricos (aumento de 23 , $4 \%$ para os $5 \%$ mais ricos e de quase $50 \%$ para os do topo da tabela - 1\%).

Em 1979, esta elite dos 1\% mais ricos arrecadava, após o pagamento dos impostos, o mesmo rendimento que cabia aos 20\% de rendimentos mais baixos; em 2007, a mesma elite arrecadava tanto como os $40 \%$ do fundo da tabela; a percentagem do rendimento nacional que cabe a estes 'eleitos' (após pagamento dos impostos) passou de 8\% em 1979 para 17\% em 2007. ${ }^{188}$ Em finais de 2009, os 20\% mais pobres dos americanos auferiam rendimentos inferiores ao nível oficial da pobreza. ${ }^{189}$ E o Censo de 2010 revelou, segundo os dados vindos a lume na comunicação social, que 40, 1 milhões de americanos vivem abaixo da linha de pobreza.

9. O recurso às políticas orientadas para provocar a baixa dos salários reais tem sido o principal expediente utilizado para tentar contrariar a tendência

187 Cfr. W. C. PETERSON, ob. cit..

188 Dados colhidos em Sam PIZZIGATI, http://toomuchonline.org/ExecScouboard.html (29.10.2011).

189 Cfr. F. GOLDSTEIN, ob. cit., 8. A diminuição da percentagem dos rendimentos do trabalho é ainda mais acentuada se deixarmos de fora os advogados de negócios, os gestores profissionais, o reduzido núcleo (1\%) dos 'colaboradores' mais bem pagos, que, no grande banquete do capital, se sentam à mesa com os maiores acionistas das grandes sociedades anónimas. Tomando apenas os EUA, dados da OCDE indicam que os 25\% dos salários mais baixos diminuíram 31\% entre 1980 e 2005, enquanto os salários dos 10\% do topo da escala aumentaram 21\%. Cfr. E. STOCKHAMMER, ob. cit., 10/11. 
estrutural no sentido da baixa da taxa de lucro. Mas a verdade é que o salário pago aos trabalhadores não é apenas um elemento dos custos de produção. É também o rendimento que alimenta o poder de compra da grande maioria da população que há-de comprar as mercadorias que foram produzidas com o único objetivo de serem vendidas no mercado e que têm de ser vendidas para que os empresários capitalistas possam recuperar o dinheiro investido e apoderar-se da mais-valia (em linguagem marxista).

Por isso, a diminuição do poder de compra dos trabalhadores não pode ser inteiramente compensada pelo aumento do consumo de luxo e de superluxo dos ricos. Esse aumento - que se tem, aliás, registado, de forma explosiva, 'queimando' para investimentos produtivos e investimentos sociais uma parte significativa da riqueza criada - não basta (como já Henry Ford e Keynes tinham percebido) para assegurar uma procura agregada que acompanhe o aumento da capacidade de produção. A sociedade de produção em massa exige um consumo de massa.

Pode aumentar a pressão consumista, usando e abusando dos instrumentos ao serviço da sociedade de consumo. Mas isso também não basta: a tentativa de compensar a redução do poder de compra dos salários através do estímulo ao consumo financiado pelo crédito (credit-financed-consumption) não chega para anular os efeitos daquela redução, e provoca a baixa generalizada e acentuada da taxa de poupança das famílias (e dos estados) e o sobreendividamento de muitas delas, que acabam por não poder pagar os encargos assumidos.

A crise económica e social aberta na sequência da crise financeira e da crise fiscal dela resultante veio confirmar o que já se sabia: ao reduzir os salários, o capital aumenta a sua taxa de mais-valia. Mas, ao fazê-lo, reduz o poder de compra dos trabalhadores, que constituem a grande massa dos consumidores, colocando em risco a realização da mais-valia, abrindo, deste modo, uma crise de sobreprodução. Porque as crises cíclicas inerentes ao capitalismo são, precisamente, crises de realização da mais-valia.

O predomínio do capital financeiro sobre o capital produtivo tem acentuado os riscos de crise nos setores das atividades produtivas (nomeadamente os setores industriais), com a crescente dificuldade do capital produtivo na recuperação do capital adiantado e com a acentuação da tendência para a baixa da taxa de lucro, uma vez que as rendas do capital fincanceiro (com realce para o capital especulativo) vêm absorvendo uma parte crescente da mais-valia global. 
10. Dados os elevados custos da tecnologia atualmente utilizada, as grandes empresas são forçadas a expandir a produção até ao limite da sua capacidade disponível, na tentativa de aumentar a sua quota de mercado e os seus lucros.

Mas esta tecnologia altamente sofisticada exige cada vez menos trabalhadores, que produzem cada vez mais bens por unidade de tempo de trabalho, do mesmo modo que a concorrência entre os trabalhadores à escala mundial facilita a adoção de políticas orientadas para fazer baixar os salários reais e acentua os efeitos destas políticas.

A financeirização da economia foi acompanhada (sobretudo nos EUA e na Europa) pela 'internacionalização' de muitas empresas industriais (isto é, pela exportação de capital acompanhada da deslocalização de muitas delas para países com mão-de-obra muito barata e sem direitos, como a China, Índia e outros países do chamado Terceiro Mundo). A outra face desta realidade é a acentuada desindustrialização das economias capitalistas desenvolvidas, com profundas alterações na estrutura da produção e do emprego, que têm provocado enorme debilidade nas estruturas produtivas dos países dominantes. E esta debilidade é o pano de fundo das políticas que têm vindo a pôr em causa a segurança do emprego, os níveis salariais e os direitos sociais dos trabalhadores dos países mais industrializados, e dificultando a criação de emprego no momento da ultrapassagem dos períodos de depressão.

Estudos referentes aos EUA indicam que os novos postos de trabalho criados no setor dos serviços oferecem, na sua maioria, salários bastante mais baixos do que os praticados anteriormente na indústria. E aqui pode radicar um fator estrutural gerador da baixa dos salários reais na sociedade americana, aumentando as desigualdades e potenciando a ocorrência de crises cíclicas, cada vez mais difíceis de ultrapassar, no que se refere ao desemprego, dada a redução das atividades produtivas na indústria: é mais difícil criar novos postos de trabalho e os que existem oferecem salários mais baixos.

Por outro lado, como é sabido, a concorrência entre as grandes empresas monopolistas (nos mercados de oligopólio) faz-se através da introdução de novas tecnologias de produção e de novos produtos. Mas as tentativas de ampliar por este meio as quotas de mercado atingem rapidamente os seus limites. Com efeito, o alto nível de produtividade das tecnologias disponíveis gera em pouco tempo um volume de produção que ultrapassa o poder de compra dos 
consumidores, e o processo de expansão é travado, porque ninguém investe para aumentar a capacidade de produção se souber que não pode vender, com lucro, os bens produzidos.

Por isso, nos últimos vinte ou trinta anos, as crises do capitalismo têm-se caraterizado por uma enorme dificuldade em retomar o crescimento do emprego: a economia começa a crescer, mas o desemprego mantém-se, a níveis elevados. Isto significa que, não recuperando o seu posto de trabalho, os trabalhadores não recebem o seu salário e não dispõem de rendimentos para comprar as mercadorias que o sistema produz para vender (única forma de realizar a mais-valia e obter lucros).

A ultrapassagem das crises do capitalismo vem-se revelando uma tarefa cada vez mais difícil de resolver, porque, nas condições referidas, não é fácil fazer arrancar o processo de acumulação do capital, traduzido na recuperação da economia e na criação de emprego. Apesar da enorme injeção de capitais públicos, a economia americana continuava a registar, em meados de 2011, 14 milhões de desempregados.

11. Do ponto de vista das nossas preocupações, é também importante tentar saber qual a relação entre o aumento dos lucros e o aumento do investimento, dado que, desde Adam Smith, os defensores do mercado vêm insistindo em que a salvaguarda das margens de lucro é indispensável para que haja investimento. Dentro da lógica do capitalismo, esta afirmação é verdadeira; mas isso não significa que o aumento dos lucros arraste necessariamente consigo um correspondente aumento do investimento.

$\mathrm{Na}$ verdade, a relação entre o aumento dos lucros e o nível do investimento diminuiu consideravelmente, nos países mais desenvolvidos (EUA, Reino Unido, Alemanha, França e Japão), a partir de meados dos anos $1970{ }^{190}$, período que coincide com o início da contra-revolução monetarista, que trouxe consigo o domínio do capital financeiro e a adaptação das 'regras do jogo' aos interesses dos especuladores. Os 'investimentos' a curto prazo na especulação tornaram-se mais rentáveis do que o investimento produtivo. Estava aberto o caminho

190 Cfr. E. STOCKHAMMER, ob. cit., 12/13. 
da financeirização do sistema, que afundou os grandes senhores do capital no mundo obscuro dos jogos de casino. Estes, como já se disse atrás, fizeram o resto.

Neste mesmo sentido atuou o processo de inovação financeira, a que nos referimos anteriormente. Os chamados investidores institucionais adquiriram um peso enorme no capital acionista das grandes empresas cotadas em bolsa. E este tem sido um dos fatores da financeirização das economias capitalistas, porque estes investidores têm privilegiado o 'investimento' em capital fictício (ativos financeiros), o mesmo fazendo os bancos, que têm exigido às empresas produtivas taxas de juro crescentes (capazes de se aproximar dos ganhos chorudos da especulação), realizando assim lucros elevados (quase isentos de impostos), que canalizam (bem como os depósitos dos seus clientes) para atividades puramente especulativas, quase sempre desenvolvidas por entidades com sede no ambiente acolhedor dos paraísos fiscais.

Por outro lado, as grandes sociedades anónimas e os seus managers abandonaram a prática tradicional de não distribuir uma parte dos lucros, a fim de canalizar para o financiamento do investimento produtivo esta poupança forçada dos acionistas. Ao invés, passaram a privilegiar a maximização do lucro a curto prazo e a distribuição de dividendos elevadíssimos aos acionistas, acompanhada do pagamento de generosos salários e prémios aos gestores que cumprem as metas. Uns e outros colocam este dinheiro nos paraísos fiscais (para isso os inventaram) e jogam forte nas bolsas-casino.

12. Como é sabido, no rescaldo da primeira grande crise do capitalismo ocorrida após um período de euforia especulativa, Keynes (1936) veio defender junto dos que, como ele, queriam salvar o capitalismo, a ideia de que a socialização do investimento tornaria o capital abundante e baixaria as taxas de juro para valores próximos de zero dentro de um prazo de 25 anos, provocando deste modo, gradualmente, sem necessidade de qualquer revolução, o que ele chamou a eutanásia do rendista, a morte do capitalista sem profissão ("functionless investor" - cap. XXIV da General Theory).

Mas a contra-revolução monetarista veio matar Keynes, enterrado a preceito, para que não ressuscitasse. E a cartilha neoliberal impôs, ao longo das últimas décadas, políticas deliberadamente empenhadas em criar as condições 
favoráveis à especulação e em proteger os que vivem das 'rendas' da especulação bolsista, das 'rendas' da especulação imobiliária e de todas as 'rendas' de tipo feudal garantidas pelo estado capitalista, agora na veste de estado garantidor.

Neste ambiente, a crise chegou, esperada e talvez programada.

Trata-se de uma crise do neoliberalismo, diagnosticaram alguns, com o objetivo de fazer passar a mensagem de que o capitalismo não tem que ver com as crises, que o capitalismo - com a sua famosa economia de mercado é intocável e é eterno, como eternas e universais são as leis que o governam.

A verdade, porém, é que o neoliberalismo não existe fora do capitalismo, não é um fruto exótico que nasceu nos terrenos do capitalismo, nem é o produto inventado por uns quantos 'filósofos' que não têm mais nada em que pensar. O neoliberalismo corresponde a "uma nova fase na evolução do capitalismo". ${ }^{191}$ O neoliberalismo é o reencontro do capitalismo consigo mesmo, depois de limpar os cremes das máscaras que foi construindo para se disfarçar. O neoliberalismo é o capitalismo na sua essência de sistema assente na exploração do trabalho assalariado, na maximização do lucro, no agravamento das desigualdades. O neoliberalismo é o capitalismo puro e duro do século xvıı, mais uma vez convencido da sua eternidade, e convencido de que pode permitir ao capital todas as liberdades, incluindo as que matam as liberdades dos que vivem do rendimento do seu trabalho. O neoliberalismo é a expressão ideológica da hegemonia do capital financeiro sobre o capital produtivo, hegemonia construída e consolidada com base na ação do estado capitalista, porque, ao contrário de uma certa leitura que dele se faz, o neoliberalismo exige um forte estado de classe ao serviço dos objetivos do setor dominante das classes dominantes, o capital financeiro. O neoliberalismo é a ditadura da burguesia, sem concessões. Mais especificamente: a ditadura do grande capital financeiro.

A esta luz, poderemos dizer que, em certo sentido, esta é uma crise do neoliberalismo (ou uma crise da financeirização). ${ }^{192}$ Com efeito, a contra-revolução monetarista trouxe consigo a plena liberdade de circulação de capitais à escala mundial; a independência dos bancos centrais; a desregulamentação das atividades do setor financeiro; o livre curso do processo de inovação financeira (criação

191 Cfr. G. DUMÉNIL e D. LÉVY, The Crisis..., cit., 5.

192 Uma caraterização desta crisis of financialisation pode ver-se em C. LAPAVITSAS e outros, Eurozone Crisis, cit., 4. 
de produtos derivados, mercados de futuros, todos os ingredientes das bolsas-casino); a prioridade absoluta conferida à estabilidade dos preços em detrimento do pleno emprego e do combate ao desemprego; a orientação das grandes sociedades anónimas no sentido de favorecer a distribuição de dividendos régios aos seus acionistas e de prémios principescos aos seus gestores, com prejuízo do autofinanciamento do investimento produtivo; a luta contra os sindicatos (nomeadamente contra a contratação coletiva); o aumento das taxas reais de juro cobradas pela banca e o aumento dos ganhos do setor financeiro, que se apropria de uma parte crescente da mais-valia, da riqueza criada no setor produtivo, que, por isso mesmo, é afetado pela tendência para a baixa das taxas de lucro; o aumento do endividamento das famílias, das empresas e dos estados.

E estes são elementos claramente potenciadores da ocorrência das crises cíclicas próprias do capitalismo e da crescente dificuldade em sair delas através da recuperação das taxas de lucro das empresas não financeiras, do aumento da taxa de utilização da capacidade de produção instalada, do aumento do investimento privado em atividades produtivas, e, sobretudo, através do aumento da produção e do emprego. Neste sentido, concordamos em absoluto com a tese segundo a qual "as últimas transformações do capitalismo [as que decorrem da ideologia neoliberal] podem conduzir a crises em que os mecanismos monetários e financeiros desempenham um papel central, aumentando a instabilidade inerente ao sistema. (...) Estas crises constituem uma componente maior dos custos do neoliberalismo". 193

Seja como for, a presente crise é, na sua essência, mais uma crise do capitalismo, uma "crise estrutural do capitalismo". ${ }^{194}$

As suas causas últimas, indo além das bolhas especulativas e dos jogos de casino que tornaram a crise indisfarçável, radicam na própria essência do capitalismo, tendo-se acentuado progressivamente à medida que se foram consolidando os resultados da mundialização feliz de que falam os apóstolos da política de globalização neoliberal dominante.

O ambiente especulativo atrás desenhado acentuou a volatilidade e a incerteza dos mercados financeiros (nomeadamente quanto às taxas de juro e às taxas de

193 Cfr. G. DUMÉNIL e D. LÉVY, "Costs and benefits..., cit., 602, e também C. CAMACHO e J. ROJAS NIETO, ob. cit.

194 Cfr. G. DUMÉNIL e D. LÉVY, The Crisis..., cit. 
câmbio), afetando negativamente o investimento nos setores produtivos. Se à baixa deste tipo de investimento acrescentarmos a baixa do consumo privado, o resultado é a diminuição da procura agregada.

A equação enunciada permite compreender não só a génese das situações recorrentes de sobreprodução, mas também o facto de estar a tornar-se cada vez mais difícil para o capital recuperar os adiantamentos feitos na aquisição de equipamentos muito caros, acentuando-se a tendência para a baixa da taxa de lucro.

Esta é a questão central que está por detrás da crise (desta e de todas as outras crises do capitalismo). E ela traduz uma contradição que o capitalismo não consegue ultrapassar, a contradição entre o nível de desenvolvimento das forças produtivas e a natureza das relações de produção próprias do capitalismo, que assentam no trabalho assalariado e pressupõem a maximização do lucro do capital.

13. As ideias que acabámos de enunciar não são ideias novas. O facto de elas terem sido deliberadamente 'esquecidas' pode resultar da atitude obscurantista dos fanáticos do deus-mercado, mas pode resultar também da vontade destes mesmos e de todos os setores do capital de, num quadro que consideravam favorável, desencadear uma crise, para, a coberto dela e sob o pretexto de a combater, acentuarem as políticas tendentes a aniquilar de uma vez por todas os direitos sociais dos trabalhadores (e, portanto, também os seus direitos civis e políticos), com o objetivo de fazer regressar o mundo aos tempos do capitalismo selvagem (que é, afinal, o capitalismo na sua essência).

A presente crise, fruto das desigualdades, vem agravando as desigualdades e vem alargando a pobreza (com um número cada vez maior de pobres que trabalham), confirmando o capitalismo a sua caraterística genética de "civilização das desigualdades".

Razões não faltam, como se vê, para deitar fora os catecismos neoliberais: no plano teórico, o neoliberalismo está completamente desacreditado, e os resultados das políticas neoliberais são consabidamente desastrosos. A verdade, porém, é que o neoliberalismo não saiu de cena: os pontos deste 'teatro do mundo' continuam a soprar aos atores em palco os mesmos textos... E os governantes de 
turno não conhecem outra cartilha. Infelizmente, até hoje a realidade confirma este diagnóstico.

Esta não será a última crise do capitalismo, mas ela ajudará a enfraquecer ainda mais este corpo condenado a morrer (como tudo o que é histórico) e a dar lugar a um mundo diferente, apesar de todos os meios - e são muitos - que podem ainda prolongar-lhe a vida.

O feudalismo deu o lugar ao capitalismo quando, ao fim de um longo período de desagregação, aquele modo de organização económico-social se revelou incapaz de garantir as rendas que sustentavam o estatuto privilegiado das classes dominantes, que já não tinham mais margem para aumentar a exploração dos trabalbadores servos. Talvez se aproxime o tempo em que as contradições do capitalismo começam a revelar a sua incapacidade para manter as rendas (verdadeiras rendas feudais) do capital financeiro. A menos que, esgotada a possibilidade de novas exigências aos trabalbadores assalariados, se recorra, uma vez mais, à barbárie extrema.

Há mais de cinquenta anos, o argentino Raúl Prebisch (o primeiro Presidente da agência da ONU Comissão Económica para a América Latina) avisou que as soluções liberais só podem concretizar-se manu militari. No início dos anos 1980, Paul Samuelson chamava a atenção para os perigos do "fascismo de mercado". Mais recentemente Paul Krugman recordava: "Somos uma sociedade em que a concentração do rendimento e da riqueza nas mãos de poucas pessoas ameaça fazer com que sejamos uma democracia somente de nome (...), uma vez que a concentração extrema do rendimento é incompatível com a democracia real". ${ }^{195}$

Se tivermos presente esta lição, compreendemos que a luta contra o neoliberalismo e contra as políticas nele inspiradas é uma luta pela democracia. E esta luta trava-se hoje também no terreno do trabalho teórico (que nos ajuda a compreender a realidade para melhor intervir sobre ela) e no terreno da luta ideológica, porque o peso dos aparelhos ideológicos ao serviço da ideologia dominante é hoje talvez o fator mais importante na determinação da correlação de forças que decide as lutas sociais e porque a luta ideológica é, hoje mais do que nunca, um fator essencial da luta política e da luta social (da luta de classes).

195 Artigo no New York Times, 7.11.2011. 
Parafraseando um poeta brasileiro (Álvaro Moreyra), uma coisa parece hoje incontestável: este mundo está todo errado. É preciso passá-lo a limpo. Aos universitários e aos intelectuais em geral cabe, como cidadãos, como universitários e como intelectuais, uma responsabilidade enorme nas lutas a travar nestes domínios, para que um dia, como nos diz a canção de Xico Buarque, possa nascer uma flor no "impossível chão". 


\section{BIBLIOGRAFIA}

AVELÃS NUNES, António José - Economia, Vol. II, O Crédito (Lições aos alunos do $5^{\circ}$ ano da FDUC), edição dos Serviços de Acção Social da Universidade de Coimbra, Coimbra, 2006.

BARROSO, Alfredo - "A crise da social-democracia europeia", em Le Monde Diplomatique (ed. port.), no 61, novembro/2011, 16/17.

CAMACHO, Carlos Morera e NIETO, José Antonio Rojas - "The Globalisation of Fnancial Capital, 1997-2008", em http://researchonmoneyandfinance.org, 15 março/2009.

CARVAlHO, Pedro - "A Crise por detrás da(s) Crise(s). Reflexões sobre a evolução do sistema capitalista do século xix à Grande Depressão", em Vértice, n 152, maio-junho/2010, 81-99.

CASSEN, Bernard e outros (Coord.), Contra a ditadura dos mercados, trad. port., Campo da Comunicação, Porto, 2000.

CASSIDY, John - How Markets Fail - The Logic of Economic Calamities, Londres, Allen Lane/Penguin Books, 2009.

CROTTY, James - "The Neoliberal Paradox: The Impact of Destructive Product Market Competition and Impatient Finance Nonfinancial Corporations in the Neoliberal Era", em Review of Radical Political Economics, Vol. 35, n 3 (2003), 271-279.

DUMÉNIL, Gérard e Dominique LÉVY - "Costs and benefits of neoliberalism. A class analysis", em Review of International Political Economy, Vol. 8, no 4, Inverno/2001, 578-607 ; - "The profit rate: where and how much did it fall? Did it recover? (USA 1948-2000), em Review of Radical Political Economics, vol. 34 (2002), 437-461;

- The Crisis of Neoliberalism, Harvard University Press, 2011.

GALBRAITH, James K. - Introdução à tradução brasileira de John Kenneth GALBRAITH, 1929 - A Grande Crise, Larousse do Brasil, São Paulo, 2010, 9-14.

GALLIN, Dan - "Reinventar a política sindical", em B. CASSEN e outros (Coord.), ob. cit., 101-122.

GOLDSTEIN, Fred - "Capitalism in Crisis" (outubro/2010), disponível em www.lowwagecapitalism.com

GREEN, David G. - The New Conservatism - The counter revolution in political, economic and social thought, St. Martin's Press, New York, 1987.

GREENSPAN, Alan - A Era da Turbulência - Aventuras em um novo mundo, trad. bras., Elsevier Editora/Campus, São Paulo, 2008.

HAYEK, Friedrich - "Unions, Inflation and Profits" (original de 1959), em F. HAYEK, Studies in Philosophy, Politics and Economics (1 $1^{\mathrm{a}}$ edição, 1967), Routledge and Kegan Paul, Londres, 1978.

HUSSON, Michel - "Uma forma exacerbada de rendibilizar o capital", em B. CASSEN e outros (Coord.), ob. cit., 51-53. 
IMBERT, Pierre-André - "Todo o poder aos fundos de pensões", em B. CASSEN e outros (Coord.), ob. cit., 41-47.

KELLY, Marjorie - The Divine Right of Capital, Berrett-Koehler, San Francisco, 2001.

LAPAVITSAS, C., A. Kaltenbrunner, D. Lindo e outros - "Eurozone Crisis: Beggar Thyself and Thy Neighbour", RMF occasional report, março/2010, em www.researchonmoneyandfinance.org.

PETERSON, Wallace. C. - "The Silent Depression", em Challenge, no de julho-agosto/1991 [utiliza-se a versão publicada em Problèmes Économiques, no 2.271, 15.4.1992, 1-6].

QUELHAS, José Manuel Gonçalves Santos - Sobre as Crises Financeiras, o Risco Sistémico e a Incerteza Sistemática, Tese de Doutoramento, Coimbra, 2009.

STERN, Gary H. and FELDMAN, Ron J. - Too Big to Fail - The Hazards of Bank Bailouts, Washington, Brooking Institution Press, 2009.

STOCKHAMMER, Engelbert - "Neoliberalism, Income Distribution and the Causes of the Crisis", em http://researchonmoneyandfinance.org, versão 0.6:17 junho 2010. 